\title{
UPAYA PENGEMBANGAN KREATIVITAS GURU PENDIDIKAN AGAMA ISLAM (PAI) DALAM PENGGUNAAN MEDIA PEMBELAJARAN
}

\author{
DAMIS \\ Fakultas Agama Islam, Universitas Indonesia Timur Makassar \\ JI. Rappocini Raya No. 171-173 Kota Makassar 90222 \\ Email: damis3870@gmail.com
}

\begin{abstract}
:
The problem of this paper is, how is the creativity of Islamic religious education teacher (PAI) in the use of instructional media and how the efforts of PAI teachers in the development of learning media and what constraints or obstacles faced by teachers of Islamic Education (PAI) in the development of creativity use learning media and How is the solution made by teachers of Islamic Education (PAI) in the development of creativity use of instructional media. Concluded that in learning Islamic Religious Education manually, in the learning process using learning media. Because in each class is prepared media LCD Prejector. But depending on the learning materials (conditional). In addition, teachers also have the creativity in using the existing learning media and use methods appropriate to the material that will convey, that is tailored to the material, objectives, methods, characteristics of students in the classroom, it is intended that the use of learning media does not deviate from materials, objectives, methods, characteristics of students so that students' understanding with the use of learning media can be more easily achieved.
\end{abstract}

Keywords: Development, creativity, Teachers, Learning Media

\section{PENDAHULUAN}

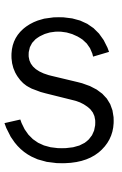

eorang guru itu perlu mengembangkan kreativitas sebagai upaya pembaharuan proses pembelajaran di sekolah, maka seorang guru dipersyaratkan mempunyai pandangan atau pendapat yang positif terhadap bagaimana menciptakan situasi dan kondisi belajar yang diharapkan. Karena secara operasionalnya gurulah yang terlibat langsung dalam proses pembelajaran di sekolah. Tugas guru memang sangatlah kompleks, sehingga mereka dituntut untuk menguasai sejumlah ilmu pengetahuan serta keterampilan yang diperlukan. Guru harus memiliki kemampuan profesional dalam tugasnya dengan menerapkan konsep teknologi pembelajaran dalam memecahkan masalah-masalah pendidikan/pembelajaran (Bakkidu, http://index.php/nurhinda bakkidu, diakses 18 Oktober 2017).

Dalam teknologi pembelajaran, pemecahan masalah itu berupa komponen sistem instruksional yang telah disusun dalam fungsi desain dan seleksi, dan dalam pemanfaatan dikombinasikan sehingga menjadi sistem instruksional yang lengkap. Komponen-komponen tersebut meliputi: pesan, orang, bahan, peralatan, teknik dan latar atau lingkungan. Namun dari sejumlah komponen tersebut, yang 
akan menjadi obyek penelitian adalah sikap guru terhadap teknologi pembelajaran dan pemanfaatan media atau alat bantu dalam proses pembelajaran. Karena seorang guru tentunya mempunyai pandangan tersendiri berdasarkan tanggapan, perasaan, penilaian terhadap teknologi pembelajaran, serta pemanfaatan media dalam proses pembelajaran (Bakkidu, http://index.php/nurhinda bakkidu, diakses 18 Oktober 2017).

Dalam proses pembelajaran, media telah dikenal sebagai alat bantu mengajar yang seharusnya dimanfaatkan oleh pengajar, namun kerap kali terabaikan. Problematika yang dihadapi oleh guru tidak dimanfaatkannya media dalam proses pembelajaran, pada umumnya disebabkan oleh berbagai alasan, seperti waktu persiapan mengajar terbatas, sulit mencari media yang tepat, biaya tidak tersedia, atau alasan lain. Hal tersebut sebenarnya tidak perlu muncul apabila pengetahuan akan ragam media, karakteristik, serta kemampuan masing-masing diketahui oleh para pengajar. Media sebagai alat bantu mengajar berkembang demikian pesatnya sesuai dengan kemajuan teknologi. Ragam dan jenis media pun cukup banyak sehingga dapat dimanfaatkan sesuai dengan kondisi, waktu, keuangan, maupun materi yang akan disampaikan. Setiap jenis media memiliki karakteristik dan kemampuan dalam menayangkan pesan dan informasi (Hamzah, 2007: 109).

Dalam menyampaikan pesan pendidikan agama diperlukan media pengajaran. Media pengajaran pendidikan agama adalah perantara/pengantar pesan guru agama kepada penerima pesan yaitu siswa. Media pengajaran ini sangat diperlukan dalam merangsang pikiran, perasaan, perhatian dan minat serta perhatian sehingga terjadi proses belajar mengajar serta dapat memperlancar penyampaian pendidikan agama Islam (Muhaimin, 1996: 91).

Media pembelajaran merupakan salah satu komponen pembelajaran yang mempunyai peranan penting dalam Kegiatan Belajar Mengajar.Pemanfaatan media seharusnya merupakan bagian yang harus mendapat perhatian guru atau fasilitator dalam setiap kegiatan pembelajaran. Oleh karena itu guru atau fasilitator perlu mempelajari bagaimana menetapkan media pembelajaran agar dapat mengefektifkan pencapaian tujuan pembelajaran dalam proses belajar mengajar (Mustikasari, http://edu-articles.com, diakses 08 November 2017).

Salah satu upaya seorang guru untuk meningkatkan mutu pendidikan adalah penggunaan media pembelajaran yang tepat dalam menyampaikan pesanpesannya. Hal ini diperuntukkan bagi siswa yang belum dapat menerima pesan yang disampaikan guru, maka penggunaan media sangat dianjurkan. Dengan demikian penggunaan media untuk menyampaikan pesan pembelajaran akan lebih dihayati tanpa menimbulkan kesalapahaman bagi keduanya yaitu murid dan guru. Azar Arsyad mengemukakan bahwa pemakaian media pengajar dalam proses belajar mengajar membangkitkan kemajuan dan minat yang baru, bangkitkan 
motivasi dan rangsangan kegiatan belajar dan bahkan membawa pengaruh psikologis terhadap siswa (Arsyad, 2003: 15).

\section{KREATIVITAS GURU PENDIDIKAN AGAMA ISLAM (PAI) DALAM PENGGUNAAN MEDIA PEMBELAJARAN}

Pembelajaran pendidikan agama Islam secara manual, dalam proses pembelajaran memakai media pembelajaran. Akan tetapi tergantung sesuai dengan materi pembelajarannya (kondisional).

Disamping itu, guru juga memiliki kekreativitasan dalam menggunakan media-media pembelajaran yang ada dan menggunakan metode yang sesuai dengan materi yang akan sampaikan. Ketika materi tersebut tentang surat atau ayat-ayat Al-Quran, maka ditekankan praktek, yang mana siswa dituntut untuk bisa menulis, membaca dan menghafal, dan ketika tentang akhlaq atau kisah-kisah maka disitu menggunakan metode ceramah. Jadi tidak semua penggunaan media pembelajaran digunakan pada semua materi. Selain pemakaian media, guru juga menggunakan atau menyiapkan potongan-potongan ayat, terjemahan, game (short card, roll playing, jigsaw, group resume, team quiz, demonstrasi, diskusi dan lainlain). Dalam berbagai macam kegiatan bermain itu, anak dapat diajari untuk bertanggung jawab, tenggang rasa, mandiri, dan sebagainya.

Penggunaan atau jenis media yang digunakan adalah multimedia projector (LCD), dimana disetiap ruangan atau kelas disiapkan multimedia tersebut. Dalam penggunaan media, guru mencoba untuk menggunakan berbagai metode mengajar dan disesuaikan dengan media yang dipakai.

Kriteria dalam pemilihan media yang ada disesuaikan dengan materi, tujuan, metode, karakteristik siswa di kelas, biaya pengadaan media yang disesuaikan dengan dana intern sekolah, hal ini dimaksudkan agar penggunaan media pembelajaran tidak melenceng dari materi, tujuan, metode, karakteristik siswa sehingga pemahaman siswa dengan penggunaan media pembelajaran dapat lebih mudah dicapai.

Ada beberapa hal yang perlu diperhatikan guru dalam menggunakan media pembelajaran untuk mempertinggi kualitas pembelajaran. Pertama, guru perlu memiliki pemahaman media pembelajaran antara lain jenis dan manfaat media pembelajaran, kriteria memilih dan menggunakan media pembelajaran, menggunakan media sebagai alat Bantu mengajar dan tindak lanjut penggunaan media dalam proses belajar siswa. Kedua, guru terampil membuat media pembelajaran sederhana untuk keperluan pengajaran. Ketiga, pengetahuan dan keterampilan dalam menilai keefektifan penggunaan media dalam proses pengajaran. Menilai keefektifan media pembelajaran penting bagi guru agar ia bisa menentukan apakah penggunaan media itu diperlukan atau tidak diperlukan dalam proses pengajaran. 


\section{UPAYA GURU PENDIDIKAN AGAMA ISLAM (PAI) DALAM PENGEMBANGAN MEDIA PEMBELAJARAN}

Dalam pengembangan media pembelajaran guru membuat persiapan dan rencana dalam menentukan program media yang mau diajarkan dan disesuaikan dengan karakteristik maupun kebutuhan siswa, dan ketika itu, metode yang digunakan adalah multimedia presentasi yang mana sebagian siswa dibentuk dalam kelompok kecil, kemudian mereka mempresentasikan hasil kerja kelompoknya kepada semua siswa dan dilanjutkan dengan tanyajawab.Pemanfaatan multimedia dalam presentasi ini biasanya menggunakan power point.Pemanfaatan power point dalam presentasi menyebabkan kegiatan presentasi menjadi sangat mudah, dinamis dan sangat menarik.Dan disini guru hanya sebagai fasilitator dan evaluator untuk mengarahkan jalannya diskusi tersebut. Adapun beberapa kelebihan dari multimedia presentasi ini yaitu:

a. Mampu menampilkan objek-objek yang sebenarnya tidak ada secara fisik atau diistilahkan dengan imagery. Secara kognitif pembelajaran dengan menggunakan mental imagery akan meningkatkan retensi siswa dalam mengingat materi-materi pelajaran.

b. Memiliki kemampuan dalam menggabungkan semua unsur media seperti teks, video, animasi, image, grafik.

c. Mampu mengembangkan materi pembelajaran terutama membaca dan mendengar secara mudah.

Selain multimedia presentasi guru juga menggunakan video pembelajaran. Video pembelajaran ini dimanfaatkan untuk memutar CD yang sesuai dengan materi yang akan diajarkan dan membimbing peserta didik untuk memahami sebuah materi melalui visualisasi. Peserta didik secara interaktif dapat mengikuti kegiatan praktik sesuai dengan yang diajarkan dalam video tersebut dalam kehidupan sehari-hari. Seperti tentang materi shalat, wudhu, kisah-kisah teladan para Nabi dan lain sebagainya.

Untuk itu, guru pendidikan agama Islam harus memiliki komitmen yang tinggi dalam pembelajaran, dimana guru agama tersebut akan selalu melakukan perbaikan-perbaikan dan pembaharuan dalam setiap pertemuan.

\section{KENDALA-KENDALA YANG DIHADAPI SAAT GURU MENGGUNAKAN MEDIA PEMBELAJARAN}

Sebagaimana diketahui bahwasanya berhasil dan tidaknya tujuan suatu pembelajaran, sangat dipengaruhi olah seorang guru. Ketika pada seorang guru ditemukan suatu permasalahan yang menjadi kendala dalam pembelajaran, maka pembelajaran tidak dapat berjalan secara optimal.

Ditemukan beberapa problem yang dihadapi oleh guru pendidikan agama Islam dalam pembelajaran pendidikan agama Islam tersebut, antara lain:

a. Lampu mati 
b. Sulitnya mencari VCD tentang materi-materi yang berkaitan

c. Salah seorang siswa memakai earphone sambil mendengarkan musik atau radio ketika pembelajaran berlangsung,

d. Kondisi di lingkungan sekitar yang kurang kondusif. Artinya, merasa terganggu oleh obrolan-obrolan siswa yang lainnya yang berada diluar, persis didepan kelas tersebut. Apalagi obrolan itu diiringi dengan gelak tawa yang keras dan teriakan.

Di samping itu, yang menjadi faktor dalam penggunaan media disekolahsekolah pada umumnya yaitu keterbatasan media pembelajaran yang dipakai dikelas diduga merupakan salah satu sebab lemahnya mutu pendidikan pada umumnya. Hal ini terlebih dirasakan pada mata pelajaran keagamaan. Pemanfaatan media dalam proses pembelajaran di bidang keagamaan dapat dikatakan belum optimal.

\section{SOLUSI YANG DILAKUKAN DALAM MENGATASAI KENDALA-KENDALA YANG DIHADAPI SAAT GURU MENGGUNAKAN MEDIA PEMBELAJARAN}

Dalam menghadapi problematika tersebut guru pendidikan agama Islam menggunakan berbagai macam langkah untuk mengatasi kendala-kendala dalam penggunaan media.

a. Langkah-langkah dalam menghadapi problematika tersebut, ketika lampu mati. Waktu itu dipergunakan dengan sebaik-baiknya, yaitu digunakan untuk setoran hafalan. Setiap anak wajib menghafal 1 Surah. Dan hafalan ini sebagai syarat untuk mengikuti ujian akhir atau dengan kata lain istilahnya disebut dengan "Training Islam" (TI).

b. Langkah-langkah dalam megatasi kesulitan mencari VCD tentang materi pelajaran.

Guru memberi arahan, dan siswa di minta untuk mencari CD yangberkaitan dengan materi pelajaran atau membuka situs tertentu yang berkaitan dengan materi ajarnya, atau memakai metode lain demi kelancaran proses pembelajaran.

c. Langkah-langkah dalam mengatasi kendala-kendala yang siswa itu kurang berantusias dalam proses kegiatan belajar mengajar saat guru menggunakan media

Guru mengadakan pendekatan pada siswa secara personal, dan memberikan stimulus, motivasi yang bisa membangkitkan minat siswa, dan menciptakan suasana yang lebih baik lagi agar selama proses kegiatan belajar mengajar berlangsung dengan menyenangkan.

d. Langkah-langkah dalam mengatasi kendala-kendala pada lingkungan kelas yang kurang kondusif dalam artian guru dan siswa terganggu orang-orang yang ada disekitar maupun diluar kelas. 
Guru harus bisa mengoptimalkan lingkungan kelas yang nyaman dan menyenangkan sebagai sumber belajar. Di samping itu guru harus bisa menguasai seisi ruangan kelas dalam arti bisa mengondisikan siswa agar perhatian, konsentrasi siswa itu tetap terfokus pada pelajaran. Dan kadangkadang guru mengajak siswa untuk belajar diluar kelas atau disekitar lingkungan sekolah yang suasananya cocok untuk dibuat belajar, agarsiswa tidak mengalami kebosanan.

Oleh karena itu, program media yang dilaksanakan secara sistematis berdasarkan kebutuhan dan karakteristik siswa serta diarahkan pada pembahasan tingkah laku siswa yang ingin dicapai.Didalam kegiatan belajar mengajar media pembelajaran secara umum mempunyai kegunaan untuk mengatasi hambatan dalam berkomunikasi.Disamping itu media pembelajaran dapat membantu memudahkan belajar bagi siswa dan memudahkan mengajar bagi guru, memberikan pengalaman lebih nyata, menarik perhatian siswa lebih besar (jalannya pelajaran tidak membosankan), lebih menarik perhatian dan minat siswa dalam belajar.

\section{DAFTAR PUSTAKA}

Arsyad, Azhar. Media Pembelajaran. (Jakarta: PT. Raja Grafindo Persada, 2003), Bakkidu, Nurhinda. Sikap Guru terhadap Teknologi Pembelajaran Hubungannya dengan Pemanfaatan Media dalam Proses Pembelajaran. http://index.php/nurhinda bakkidu. Diakses 18 Oktober 2017.

Hamzah. Profesi Kependidikan. (Jakarta: PT. Bumi Aksara, 2007).

Muhaimin. Strategi Belajar: Penerapan dalam Pembelajaran Pendidikan Islam. (Surabaya: CV. Citra Media, 1996).

Mustikasari, Ardiani. Mengenal Media Pembelajaran. http://edu-articles.com, diakses 08 November 2017. 